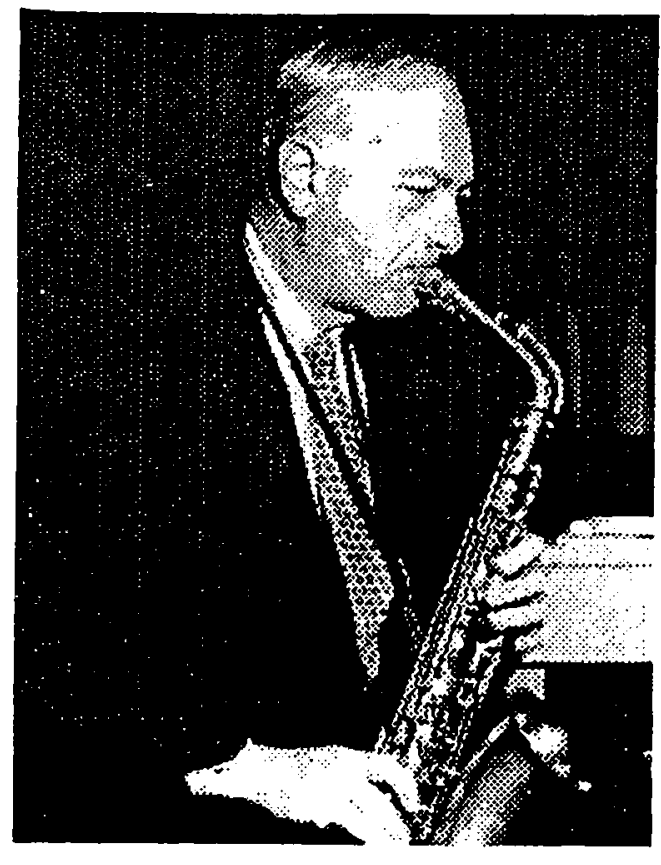

Dr. Carroll Clark, Chair of the Department 1931-1962.

Renowned for his saxophone playing at ASA meetings and local radio shows.

Dr. E. Jackson Baur joined the faculty in 1947. He is now Professor Emeritus. Department Chair 1970-1973.

\section{STREETCORNER SOCIOLOGY}

\section{Jean Van Delinder}

University of Kansas

Mid-American Review of Sociology, 1991, Vol. XV, No. 2:59-69

Sociology at the University of Kansas is steeped in the ethnographic tradition of the "Chicago School." This is the result of a continuous exchange of promising graduate students and faculty between the two departments. Dr. E. Jackson Baur is a part of the "Chicago connection." He was awarded the Ph.D. by Chicago in 1942 and was hired as an Assistant Professor by the University of Kansas in 1947. He has been Professor Emeritus since 1983 and still maintains an active involvement in the department. The following is an informal history of Dr. Baur's experiences as a student at Chicago and as a professor at Kansas.

Sociology at the University of Kansas has been predominately "humanistic." Frank W. Blackmar, the original chair and founder of the department addresses such topics in his prolific writings on Spanish Institutions of the Southwest (1891), Spanish Colonization in the Southwest (1890), and Social Degeneration in Towns and Rural Villages $(1900){ }^{2}$ As director of the "Social Surveys Series," Blackmar coordinated five ethnographies, two of which Ernest W. Burgess contributed to. Burgess conducted his first ethnographic community studies in Lawrence before accepting an appointment in Chicago in 1915. Through the use of surveying techniques Burgess studied "the social conditions" of Belleville and Lawrence, Kansas (Sica 1983, p. 609). Thirty-two years later, Dr. E. Jackson Baur was recruited to the University of Kansas because of his skills in survey research and community studies. Baur conducted numerous studies involving surveys and opinion polls on topics ranging from teenage drinking habits to attitudes of farmers toward construction of a dam that would alter their communities.

"Streetcorner sociology," though prolific at Chicago, was also common in Kansas. There was a long standing tradition for promising graduate students to complete the Ph.D. at Chicago rather than Kansas. In return, several Chicago faculty members have been recruited to the University of Kansas Sociology Department. The tradition of using the community as a workshop is evident from a quick perusal of M.A. and Ph.D. topics: "A Survey of the Fraternity Situation at Kansas University" (1916), "Comerio; a Sociological Study of an Island Puerto Rican Town" (1936), "A Social Study of a CCC Camp" (1938), "Small Town in Modern India" (1969). ${ }^{3}$

Dr. E. Jackson Baur is a sociologist trained at Chicago and a member of the Kansas faculty for forty-four years. As part of the Sociology Department's Centennial Celebration in the Spring of 1991, I interviewed Dr. Baur about his tenure as a graduate student and his professional career at Kansas. As much as possible, I will let Dr. Baur speak for himself. 
II started college in 1931. Within those first two years I decided to major in sociology. I remember I read an introductory textbook with a chapter written by Seba Eldridge, then a faculty member at the University of Kansas. [Baur spent his freshman and sophomore years attending Washington University at St. Louis.] Anyway, I applied at the University of Chicago and was admitted. I went on to complete my Bachelor's there as well as my Master's and Ph.D."

Baur completed the M.A. in 1938 under the direction of W. Lloyd Warner. He supported himself by directing a WPA (Works Progress Administration) funded research project from 1936 to 1939 . "It was a study of a Mexican neighborhood in Chicago on how people adjusted to urban life. Most of them had been in Chicago from ten to fifteen years. The project focused particularly on the young men because it was part of a larger study of juvenile delinquency. Mexicans had a rather low rate of delinquency at that time in Chicago. But at any rate, that was the objective, though Warner's primary interest was in the structure of the community. I was fortunate to get this position, because it subsidized my research and gave me a great many resources, particularly staff. This was a time, in the middle of the Depression, when the WPA was funding social research."

Sociology in the mid 1930s was a relatively new discipline. American Joumal of Sociology was the oldest journal having been established in 1895 . American Sociological Review and Social Forces were only a few years old. Baur recalled reviewing every article published in those journals to study for the theory portion of his doctoral written exam. The written exam was in four parts. The first was General and Historical (theory) directed by Lewis Worth and Herbert Blummer. The second part consisted of Social Psychology also directed by Herbert Blummer. The third section was on Community and Institutions under Everett Hughes and W. Lloyd Warner. The final portion was on Statistics prepared by William Ogburn and Samuel Stouffer. Doctoral candidates were also required to have a minor in a related department. Because of his interest in communities, Baur chose eultural anthropology.

Baur completed the written doctoral examinations in 1939 and took a position as Instructor of Social Anthropology at Dillard University in New Orleans. In that same year he married Lillian Jacobey.

"I taught for two years at Dillard, which at that time had an enrollment of about 300 students. It should have been called a college, but it presumed the status of a university, because it also had a nursing school.

"This was a Black college, and I was one of the three white faculty members out of a total of 27 . My friends were among the Black faculty. It was a very interesting experience, because we really lived on the other side of the color line. One of the early things I remember happening was that I was taken for Black frequently. You wonder how someone could be taken for black who had blue eyes and reddish hair.

"Perhaps one of the best examples of how this case of mistaken identity could occur was when a Black minister from Baltimore, apparently very distinguished within his community, and his sister visited New Orleans. A reception was held for them at the university. You know how receptions are People come in and they chat with the honored guests and have a bite to eat and that sort of thing. As my wife and I were leaving we spoke to them. The sister of the honored guest said to me, 'You know, you so much resemble a cousin of mine, I wonder if we are not related.' I said, 'Well, who is he?' And she said, 'Walter White.' Walter White was the head of the NAACP at that time. He was a man who was perhaps a little darker than I am, but not much. I had met his brother who was also active in educational circles. So perhaps I could see how she could see a resemblance.

In a social setting, people just decide what race you are by where you are and whom you are with. All sorts of other little things would happen. For instance, things were more segregated then. We went to the movies with my Black friends, and we sat in the balcony. We bought the tickets at the Black door. I could not have taken my Black friends to the white section."

Baur received the Ph.D. in 1942. He changed his dissertation advisor from W. Lloyd Warner to Everett C. Hughes. ${ }^{4}$ His original topic was to study a community of Creoles living in the Ozark region of Missouri. This Creole enclave had somehow settled in Missouri before it was part of the Louisiana Purchase. Funding for this research never materialized and he was forced to switch topics. He finally settled on the advertising community and his topic was "Voluntary Control in the Advertising Industry" (Baur 1942). He studied the growth of the advertising industry from the 1880s to the early 1920s and tried to determine "[u]nder what conditions is competition through individual enterprise supplemented by voluntary control through collective action" (Baur 1942, p. 298). Collective behavior, social control, and conflict resolution were all areas of interest to Baur throughout his academic career.

Because there were no jobs for sociologists during World War II, Baur took a position with the National War Labor Board. He was involved in labor-management mediation and the administration of the wage freeze. A year later he was inducted into the Army and served with the Corps of Engineers in Europe. After armistice in the spring of 1945, he obtained a transfer to the Research Branch of the Information and Education Division. His job was conducting surveys of soldier's opinions, some of which were later published in The American Soldier.

Soon after Baur returned home at the end of 1945 he joined the research staff of the Veteran's Administration, which was modeled after the Army's Research Branch. However, he continued to seek a teaching position in sociology. Early in 1946 he was interviewed at the University of Kansas, but turned down their offer of an assistant professorship at a salary of $\$ 3,100$. A year later they made him a new offer at $\$ 3,800$ which he accepted.

"As a junior faculty member I was assigned to teach at the least desirable hour: eight in the morning. I usually taught eleven hours of undergraduate classes as well as some tutorials and small seminars for a total of usually fourteen hours. As my appointment was in both anthropology and sociology, I taught courses in both disciplines. The seminars that I taught usually had only about three or four students in them. So, when I say I taught fourteen 


\section{Mid-American Review of Sociology}

hours it sounds worse than it really was. Classes were held on Monday, Wednesday, and Friday or Tuesday, Thursday, and Saturday. The Saturday classes were discontinued soon after I arrived at the University because of low attendance. The administration did not count graduate work as part of one's normal load, strangely enough. Our graduate enrollment was not large, but $I$ often offered a seminar for graduate students, or a research methods course. I was kept very busy."

Even though he had been earning a higher salary working for the Veteran's Administration, Baur accepted the offer from Kansas because he wanted to return to teaching. At the same time, he was considering another offer from Washington State University, but considered Lawrence, Kansas "a little closer to civilization."

When Dr. Baur arrived at the University of Kansas, the Department of Sociology was housed in a two-story wooden military barracks building. "Our expectations were not very high in those days. Our offices were on a second floor in a wooden barracks called Annex E. It was one of five annexes north of Strong Hall [the main administration building] that the university used for classrooms and faculty offices. In a sense it was an improvement. The department moved there from the basement of old Fraser Hall, where there were no windows. As I recall, the faculty were all housed in one big room. There were no separate offices. Space was tight since there had been no new construction since before the depression, in the late 1920s.

"Of course I was assured that Annex E was a temporary location for the department. Sixteen years later we were still there! All the faculty shared offices, including the chair, Carroll Clark. [Clark was also a University of Chicago Ph.D.] In fact, he not only shared an office with Marston McCluggage, he shared a desk. They sat facing each other. McCluggage would become annoyed at the constant interruptions from visitors and telephone calls Clark received. At that time there was only one secretary for the faculty, and as chair, Carroll Clark was not excused from a full teaching load. The administration was very strict about this. When faculty members retired they went on half salary and were theoretically considered to be on a half-time teaching appointment. If they moved away from Lawrence, say to Florida, they would lose their salary as they would not be within commuting distance to the University to teach classes if need be. If they died, their widows received nothing.

"I came to KU partly because my background was in survey research and partly because my minor field for my Ph.D. was in social anthropology. At that time, sociology and anthropology were one department. So I was also responsible for teaching anthropology courses in light of the fact the department had just lost their full-time anthropologist and brought me and Carlyle Smith from Columbia to teach the anthropology courses.

I was an Assistant Professor for just two years, and was promoted to Associate Professor in 1949. Wayne State was interested in recruiting me and though they did not make a formal offer, their interest was enough that think Clark [the department chair] told the Committee, 'Look, I'm going to
Streetcorner Sociology

lose this man if you don't give him a promotion.' I stayed at that rank for ten years until 1959 when I was promoted to full Professor. Many things happened during this period. Soon after I arrived, I was contacted by a social scientist in Kansas City who had been hired to establish a new program of research that was called the Institute for Community Studies. The result was that from 1949 to 1953 I worked in Kansas City every Thursday, and full-time in summer. I don't think I had a formal title, but I functioned as a consultant. I took my first sabbatical in 1953-1954.

"Of course they did not tell me this at the time, but by taking a sabbatical I excluded myself from a pay raise. They did not count the year that you were gone. You had to wait until a year after you were back before you were eligible for a merit increase. In any case, during my first sabbatical I commuted to Kansas City, working full time for the Institute for Community Studies.

In 1949, I offered a new course on survey research. It had a different name then; the name has changed over time. But the content of the course was the same. It was a course on how to do surveys and analyze people's opinions. This was tied into another development that occurred in the middle fifties which was an opportunity to join with some other KU faculty members in research on high school students' experiences with alcoholic beverages. This came about because a foundation based in New York was interested in having research done in this area. They had already funded one study done on Long Island, and they wanted ones in other parts of the country. So they arranged for one in Wisconsin and then one here. They presented themselves as wanting an objective study of high school students' experiences, but they had a hidden agenda. What these people really wanted to find out was whether or not students drank because of their upbringing. Family and community influences had a great deal to do with whether or not high school students drank, particularly family environment. So we had questions that could get at this. They weren't entirely happy with some of our analysis, because it didn't come out quite as clear cut a picture as they would have liked. But we stood our ground.

"We went ahead with the study. A group of us, who talked this over a bit, brought some research money into the department, which also provided an opportunity for employment for graduate students. My job was primarily with the development of the methods we were using and the sampling procedures. Again, my background in survey research was useful. We did a study on some 3,000 Kansas high school students and studied two different areas having contrasting characteristics. One was Wichita, Sedgwick County actually, and the other was the three tiers of eastern counties, except those in metropolitan areas. We called it a nonmetropolitan sample. But it wasn't a rural sample either. It included many small cities, including Lawrence. But from Oklahoma to the Nebraska border, we drew a sample of students from high schools, and then teams of us, led by a faculty member with a couple of graduate students, went out and interviewed. We prepared our questionnaires 
Mid-American Review of Sociology

and trained the interviewers and assembled all these data, and the findings were published by this foundation. It was worthwhile research.

"Another piece of research came along that was important to me. In the late 1950s as the Army Corps of Engineers announced that they were going to build all these dams in the valley of the Kansas River. Of course, many people didn't like that idea, the farmers particularly. So it attracted a lot of public attention. One of the sites was here at Clinton [Lake]. It occurred to me that perhaps it would be interesting to study the attitudes of people before the Clinton dam was built, but after it was decided it was going to be built. We constructed an area probability sample of the Wakarusa Valley and interviewed a sample of around 125 households in that area. This was after the announcement had been made, but before any plans had been drawn up. When it was announced, some of the farmers in the area got together and decided that they would circumvent the need for a dam by organizing a watershed district. The state of Kansas authorized under law the formation of such districts. They had begun to organize. Our research then was focused on the before and after consequences of this campaign and how it affected people's attitudes toward the proposal of building a dam. So a year later we interviewed the same people after this campaign by the local people to organize a watershed district. They had accomplished their objective of educating people about this. So we found out how people's opinions changed and then related this to various factors that influenced their thinking, such things as the location of their farm land. If it was in the flood plain, or up in the hills, or if it was downstream from the proposed dam or upstream. But then some subtle ones, like what organizations they belonged to and what meetings they had attended, and who they talked to about the issues involved. Our main thesis was that the thing that had the greatest impact was the judgement and opinions of people who were close to them socially, members of their family, neighbors and that sort of thing. Members of their more intimate groups and associations had more power over their thinking than propaganda, such as newspaper articles. This research made a convincing demonstration."

Baur was responsible for adding several courses to the curriculum. "I introduced a number of new courses, both in sociology and anthropology. This one on survey research was just the first. There are a number of others. I want to talk about some of them. In 1951, I introduced a course on social organization, which was strongly anthropological. In 1957 I offered a new course called "Religion and Society." I offered a course on what I later called "Freedom and Constraint," that was one of my favorites. It was originally called "Social Control," but after the student disturbances in the 1960s, I found a more appealing title in "Freedom and Constraint." "Social Control" sounded too much like dictators trying to suppress the masses. The basic theme of the course was actually how societies cope with the problem of tolerating or maximizing freedom while avoiding chaos and anarchy. I used a lot of materials from other cultures and studies of primitive peoples showing how societies handled this problem at different times and places. I introduced an undergraduate course in social research in 1963. Previously I had taught a methods course for graduate students only."

Throughout his teaching career, Baur used the "case method" in his classes. The case method was encouraged by the chair, Carroll Clark, who was introduced to it by the Harvard Business School. "I think the case method was a good idea, but it was especially suitable for collective behavior, social organization, and social problems. We also used it for introductory sociology. I think the encouragement here came from the Chancellor at that time, Dr. Malott, who had Harvard ties and had learned about and been involved in the Harvard Business School program. University money was provided to people who wanted to take a year off and study at the Harvard Business School.

I think the case method had a lot of merit. It gave students a concrete body of material, much of it was reports of actual events with nothing hypothetical about any of it. It may have come from personal experiences, journals, literature, newspaper reports. I effectively used articles that ran in the New Yorker on whaling. They dealt with the role of the whaling inspector. $\mathrm{He}$ has a very interesting role because he is caught between two pressures. The whaling ship is under pressure to maximize its catch and he, as the representative of the International Whaling Commission, is committed to limit the number or the size of the whales or the sex or age of the whales. He can overrule the captain, but obviously these aren't easy decisions to make.

"There was an excellent article in Harpers on the meat inspector. I got fascinated with the role of inspectors. They really have a rough life. These cases are very successful in class because students can identify with this guy. What kind of decision is he going to make? He's probably being given free steaks to take home to his family and he is expected to say this carcass is too diseased and you can't slaughter it? I found it an excellent medium. In courses in human relations I used nothing but cases, except a few supplementary readings, which just developed the theory of this approach and were not sociological. We used a book by Stuart Chase who was a popular writer and no other textbook. In other courses we had a textbook and asked the student to purchase case books. When I taught this course on "Freedom and Constraint" I used a lot of case material. In general the structure of the class was quite conventional, except that these cases were used as a functional equivalent of a laboratory exercise. Instead of dissecting a frog we dissected a factual report of a real situation."

The sociology department is now housed in "new" Fraser Hall, constructed in the early 1960 s. When sociology was finally moved out of its temporary housing, anthropology was made a separate department. "The anthropologists had grown in numbers, and they felt that they could stand on their own feet and that they could get a bigger share of the pie if they were a separate department. I recognized that this was legitimate, although I had always had a strong conviction from my graduate, and even my undergraduate studies, that social and cultural anthropology and sociology really dealt with a common problem. And that we gained a great deal in understanding societies by using a comparative approach, and looking not just at our society, but at the range 
of societies. So I wanted to have a common elementary course that approached society in that way. However, after the separation of the departments, the anthropologists wanted to start their own introductory courses, so that didn't pan out. So I initiated a new introductory sociology course called "Comparative Societies," and that is the course in which I used this approach.

"Actually, I had courses that were cross-listed with anthropology, but the anthropology advisors were biased in favor of their own staff. A lot of anthropology students took courses with me, but it wasn't part of their core curriculum. So this new course, 1 felt, filled that need. "Comparative Societies" was organized around a series of case studies on different societies from simple to complex. It started with the Bushmen in the Kalahari Desert, a most primitive and simple people, and ended with modern industrialized society, the industrial revolution in England. And others that ranged in between with different degrees of complexity and technological development. That course is still being taught regularly.

"When I first came we had a hand cranked calculator. It had a hand crank and we flipped it over to get the right decimal position. We also had a hand cranked adding machine. We had nothing like a statistics lab. When we moved here [Fraser Hall] we had more space and got a federal appropriation for some equipment in the department. The building was built by the State, but much of the equipment was a federal grant. Dr. Charles Warriner chaired the building committee. ${ }^{5}$ He worked with the architects on the design. He solicited the faculty members for their wish lists, and he did a pretty could job accommodating everyone. For instance, the two rooms with a glass partition was my idea for interview training. I wanted students to be able to interview or be subjects themselves. I was also interested in survey research and saw that as a laboratory for training people, and I used it when I taught a course on survey research. That figured in my employment here, it was one reason why I was hired. When I came here it was one of the courses I instituted because the administration wanted it. Gordon Erickson, who was a social demographer in the department, designed a whole area, the southwest corner, as a laboratory for demographic work. There were drafting tables in there and also a photographic dark room."

Baur has seen many changes in the department and the university during the last forty-four years. One of the most interesting periods was the late 1960 s and early 1970s. 'T'd say that the period of student unrest did not affect me seriously. I did think it was a backwards step to loosen requirements for students, to weaken or water down the requirements. Our department, for instance, virtually eliminated all undergraduate requirements for the major. The instructions were to take any 25 hours. I preferred to have a more rigorous set of core courses to given them a common body of knowledge of research and theory.

"I didn't think the student unrest was bad or totally inappropriate. I'd say this was reflected, too, in my tolerance of the Chancellor's approach to the problems. He was under fire from some people who thought he should crack down on the kids and not tolerate all this foolishness. I respected him for what he did. I thought he kept a lid on it pretty well. He didn't survive for that reason and others."

Baur has long been involved in human rights activities. "One of the burning issues in Lawrence when I came here in 1947 was racial discrimination. Having this background of teaching in a Black college, of course, I was involved. A local group was organized in 1946 when a Black veteran was refused admission or maybe just didn't want to sit in the right place in what is now Liberty Hall. The result was that a number of people, most of whom were associated with the University, and Black leadership, formed an organization called the Lawrence League for the Practice of Democracy. I joined this organization and made many friends. We were more successful on campus than in town. Things like integrating the dormitories. Blacks were not allowed in university dormitories when we came here. Blacks did not eat with white students in the cafeteria. This was maybe partly self segregation. I can't remember all the problems, but of course public services in town eventually had to comply with desegregation.

The theatres were our particular target. One theatre called the Pattee Theatre did not admit Blacks at all. What is now Liberty Hall only permitted Blacks to sit in the balcony. The Granada Theatre, which only has one floor, had white stripes painted around the chairs of the back couple of rows where Blacks could sit. So we put pressure on the man who ran all the theatres. They were all under one management. After some pressure, he did make some changes. Eventually the theatres were integrated."

In addition to his teaching and research, Baur was a Fulbright lecturer at the University of Amsterdam in 1961-62. While in Amsterdam, Baur was invited to lecture at the University of Istanbul and the Middle East Technical University in Ankara. In 1968-69 he had another Fulbright to lecture in Vienna at the Interpreter's Institute. Perhaps his most frustrating experience was as Resident Scholar to the Board of Engineers for Rivers and Harbors, U.S. Army, Corps of Engineers in Washington, D.C. in 1972. T was the sole social scientist trying to convince engineers that building dams would significantly alter long established community structures. That this would have a traumatic effect on the lives of the people involved. For these engineers, the 'human element' was an insignificant factor in designing a flood control project."

His last sabbatical in 1976-77 was as a Visiting Fellow at the Social Change Study Center at the Battelle Human Affairs Research Centers in Seattle, Washington. His area of research was conflict resolution, a lifelong interest to him. Upon returning to his academic appointment, Baur tried to implement an interdepartmental major in Conflict Regulation and Management. He spent five years overcoming the opposition of professors in related fields who feared the innovation would encroach on their area of expertise, and the resistance of administrators reluctant to approve a controversial program with an unpredictable future. "It was basically a turf war between several schools. Each discipline thought they were the expert, the best suited to providing a major in that subject area." The program was never imple- 
mented. Baur retired before he could persuade university administrators to provide the needed support. However, he did establish the E. Jackson Baur Award for Research and Study of Social Conflict and its Resolution in 1986. It is an interdepartmental award, open to students in anthropology, communication studies, history, philosophy, political science, psychology, social welfare, and sociology.

Baur was asked to serve as Acting Chair of the Department in 1967-68. In 1969 he formally became Chair and served in that capacity until 1972. During that time he re-organized the structure of the department and wrote by-laws. Students were given representation on departmental committees and could participate in recruitment decisions for faculty and graduate students. "Faculty Meetings" were renamed "Department Meetings," open to all graduate students and not just limited to their representatives.

Since becoming Professor Emeritus in 1983, Dr. Baur continues to be active in community, university, and departmental issues.

\section{ENDNOTES}

1. Information for this article is a compilation of three interviews the author conducted with Dr. Baur and portions of an oral history conducted by the KU Retiree's Club.

2. For a much more thorough discussion of the influence of Frank Blackmar on Kansas Sociology and the development of the profession in general, see Fritz (1990) and Sica (1990, 1983). An interesting sidenote comes from an interview I conducted with Barbara Olinger, daughter of Stanton Olinger who completed the first Kansas Sociology Ph.D. in 1916. Miss Olinger, who is in her nineties, recalls taking "Elements of Sociology" from Blackmar in 1921. She not only found the course difficult, but considered Blackmar to be "intimidating."

3. A complete list of the Sociology department's M.A. theses and Ph.D. dissertations (1897-1989) was compiled through the tireless efforts of Gary Foulke and Stephanne Zale, fellow graduate students at the University of Kansas. KU Librarian Bessie Wilder had catalogued all theses through 1958 , but no separate listing for sociology by date, author, and topic was compiled until 1991. It was the onerous task of Foulke, and Zale to look up every thesis and dissertation by author and year. The resulting composite list provides a handy reference for research.

4. Years later when Hughes was visiting professor at the University of Kansas, Baur learned that he had been Hughes' first doctoral candidate.

5. Dr. Charles Warriner, former chair of the department and now Professor Emeritus. He also received his Ph.D. at Chicago. Another faculty member with a Chicago Ph.D. is William R. Arnold.

\section{REFERENCES}

Baur, Edward Jackson. 1942. "Voluntary Control in the Advertising Industry." (Ph.D. dissertation, University of Chicago).

Fritz, Jan M. 1990. "Notes From the History of American Sociology: Frank Blackmar's Last Years at the University of Kansas." Mid-American Review of Sociology 14:13-26.

Sica Alan. 1990. "A Question of Priority: Small at Chicago or Blackmar at Kansas?" Mid-American Review of Sociology 14:1-12. 1983. "Sociology at the University of Kansas, 1889-1983: An Historical Sketch." The Sociological Quarterly 24 (Autumn):605-623.

Wilder, Bessie, Comp. 1949. University of Kansas Graduate School Theses, 1888-1947. Library Series No. 2, Lawrence, Kan.: University of Kansas Publications.

.1961. University of Kansas Graduate School Theses, 1948-1958. Library Series No. 12. Lawrence, Kan.: University of Kansas Publications. 